\section{A "new" influenza virus}

Last winter the influenza $A$ virus behaved in a quite unexpected way. A new subtype, A/USSR/90/77 $\left(\mathrm{H}_{1} \mathrm{~N}_{1}\right)$, appeared and spread to most countries of the world; but its effects were confined almost entirely to children and teenagers. Though many human viruses survive and spread when only children are susceptible-measles and chickenpox, for example-the worldwide spread of an influenza A virus when most adults are immune is unique, at least since laboratory studies of the virus began in 1933 .

The new virus closely resembles the $\mathrm{H}_{1} \mathrm{~N}_{1}$ influenza viruses of 1947-57, and most people older than about 23 possess serum antibody to its surface haemagglutinin antigen. Influenza virus subtypes may reappear as serious human pathogens at long intervals but only when most of the world population is again susceptible. When the Asian virus $\left(\mathrm{H}_{2} \mathrm{~N}_{2}\right)$, for example, appeared in 1957 many people over 75 had specific serum antibody to the

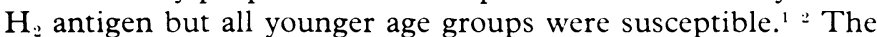
events of the last decade, which has seen the brief reappearance in man of the A swine virus in 1976 and the worldwide spread of so many variants of the A/Hong Kong $\left(\mathrm{H}_{3} \mathrm{~N}_{2}\right)$ subtype, ${ }^{3}$ have not only stimulated research but also deepened the mysteries of influenza epidemiology.

The World Health Organisation sent out warning of the new virus in mid-December 1977, as soon as it had been identified as the cause of outbreaks of influenza among young people in the USSR and Hong Kong. The virus had, however, been recognised in China as early as May 1977 and in the Philippines in June." Serological surveys soon showed that many people born before about 1957 possessed serum antibody to the haemagglutinin $\left(\mathrm{H}_{1}\right)$ of the virus, though those over the age of about 50 had it less often than did younger adults. Clinical protection appears to have been fairly well correlated ${ }^{5}$ with having lived during the time when the $\mathrm{HswN}, \mathrm{H}_{0} \mathrm{~N}_{1}$, or $\mathrm{H}_{1} \mathrm{~N}_{1}$ viruses were prevalent-that is, from 1918 to 1957; the haemagglutinin antigens of these viruses are now considered to be related.

Formerly, when new influenza A virus subtypes had emerged the preceding antigenic subtype rapidly disappeared throughout the world-but not on this occasion. The epidemic in Britain ${ }^{6}$ was similar to that in other countries. Influenza was first reported in December 1977 in an outbreak (in a geriatric unit) caused by the A/Victoria/3/75 $\left(\mathrm{H}_{3} \mathrm{~N}_{2}\right)$ virus, which had been responsible for influenza in Britain in the winter of 1976-7. A further variant of the $\mathrm{A} / \mathrm{H}$ ong Kong $\left(\mathrm{H}_{3} \mathrm{~N}_{2}\right)$ virus, designated $\mathrm{A} / \mathrm{Texas}$ $1 / 77$, was also detected, sporadically, in January 1978-the month when the $\mathrm{H}_{1} \mathrm{~N}_{1}$ virus, $\mathrm{A} / \mathrm{USSR} / 77$, was first isolated. All three influenza $\mathrm{A}$ viruses remained prevalent throughout the remainder of the winter, with a peak in late February. The epidemic was generally mild, and children were mostly affected; severe outbreaks, which were mainly in boarding schools, were often due to the $\mathrm{H}_{1} \mathrm{~N}_{1}$ virus-though this subtype was isolated only occasionally in Scotland.

The origin of the new $\mathrm{H}_{1} \mathrm{~N}_{1}$ virus is unknown. An antigenic shift to a new subtype seems to arise either from genetic recombination in a host coincidentally infected with more than one influenza virus (of human or animal origin) or from direct crossing of the species barrier by a strain from a non-human reservoir; the latter probably occurred in the A/New Jersey (swine flu) outbreak in Fort Dix in 1976. The selection of a mutant virus is theoretically possible, though the molecular biology of the influenza virus suggests that this is unlikely. Could the present virus, however, simply have remained latent for some 25 years, either in a living host or, perhaps, in a laboratory deep freeze? The A/USSR/77 virus not only closely resembles genetically the $\mathrm{A} / \mathrm{FW} / 1 / 50\left(\mathrm{H}_{1} \mathrm{~N}_{1}\right)$ isolates of $1950 \mathrm{but}$ is also similar to laboratory strains in its ability to grow well in eggs. ${ }^{5}$ Although we have no other evidence for this possibility, the events underline the need in all countries for proper containment facilities in laboratories, a matter that has had considerable attention in Britain in recent years. ${ }^{8}$
Whenever antigenic variation is recognised in the influenza virus and a new strain seems capable of causing outbreaks, vaccines may need to be updated. Most people under 24 years are still susceptible to the $H_{1} N_{1}$ virus; and the elderly, with their low resistance to infection, may also be at some risk. $\mathrm{H}_{1} \mathrm{~N}_{1}$ virus antigens should therefore be included in the vaccines for protecting both elderly and young people at special risk next winter. Children may need two spaced doses of $\mathrm{H}_{1} \mathrm{~N}_{1}$ antigen. " For most adults, though vaccine containing A/Texas/77 $\left(\mathrm{H}_{3} \mathrm{~N}_{2}\right)$ antigens should suffice, $\mathrm{H}_{1} \mathrm{~N}_{1}$ antigens in the next vaccine could provide a helpful boost to their immunity against possible further epidemics of this "new" virus.

${ }^{1}$ Mulder, J, and Masurel, N, Lancet, 1958, 1, 810 .

2 Clarke, S K R, et al, Lancet, 1958, 1, 814.

${ }^{3}$ British Medical fournal, 1976, 1, 730.

4 Weekly Epidemiological Record, 1978, 53, 67.

${ }^{5}$ United States Public Health Service, Influenza Virus Vaccine Workshop, 12 Fanuary 1978. Summary Report and Conclusions. Bethesda, Department of Health, Education and Welfare, 1978.

${ }^{6}$ British Medical fournal, 1978, 1, 1221.

Stuart-Harris, C H, and Schild, G C, Influenza. The Viruses and the Disease. London, Arnold, 1976

${ }^{\circ}$ British Medical fournal, 1978, 1, 871.

${ }^{9}$ Weekly Epidemiological Record, 1978, 53, 51.

\section{Supplying the NHS}

The NHS is not getting the best value for money for the goods it buys; nor are those who use the items getting the most efficient service from the supplies organisation. These unsurprising conclusions come from the report of the Supply Board Working Group' appointed last August (under the chairmanship of $\mathrm{Mr}$ Brian Salmon) to examine the supply of goods and equipment to the NHS. It represents the sixth inquiry of this kind since 1948, and many of its recommendations echo those of earlier reports. ${ }^{2-5}$

The NHS spends about $f 700 \mathrm{~m}$ on items ranging from cornflakes to computers ( $£ 170 \mathrm{~m}$ of it on medical equipment). About $80^{\circ}{ }_{0}$ of the total expenditure goes on items that are in common use throughout the NHS; but altogether $40^{\circ}{ }_{0}$ of the money is spent on uncoordinated purchases-often in ludicrously small orders-made by districts and hospitals. The working group considers this to be wasteful and inefficient.

The responsibility for supplies policy and implementation is split among the DHSS's supply division and regional and area health authorities. Because of this fragmentation there is a serious lack of information on purchases, stocks, and patterns of use and a tendency among authorities to disregard contracts made by higher authorities. Both these factors prevent the NHS from putting its enormous purchasing power to best use and providing the user with the best service.

Other shortcomings found by the working group include uncoordinated evaluation, especially for medical equipment; a lack of standard specifications for similar items; and the inability or reluctance of contracting authorities to commit themselves to buying specified numbers of items so that they can secure better terms. None of these findings are new. Nor are the recommendations, which are (among others) that supplies should be bought at the most economic level; that a national computerbased information system should be developed; and that authorities should whenever possible make firm, fixed-quantity contracts. Many of the report's suggestions have been made before and have not been challenged in principle: they just have not been implemented.

Because of the need for some element of compulsion and central co-ordination the working group has suggested that a central supply council should determine supplies policy, leaving staffs of supply division and NHS authorities to implement it. The council, to which Mr Ennals has given his approval, subject to consultation, would have 20 members drawn 
mainly from the NHS (including two doctors) with one representative from industry. As well as enforcing the working group's own proposals, the council's major task would be to determine "the best level and method of purchase [for each supplies item] having regard to the needs of the Service, industry, and the national economy."

The supply council is a compromise between the need for central co-ordination and the 1974 principle of delegated authority. Whether it is workable remains to be seen. If it succeeds in developing a comprehensive information system so that users-clinicians among others-can make informed choices then it will benefit both doctors and their patients. ${ }^{6}$ : But the council's continuing task is to decide the correct level of purchase for each item of supplies. Nowhere does the working group say what it means by item or deal with the problem of how the council's members, who all have other jobs, will cope with the sheer size of the work load and yet remain sensitive to the needs of users. The danger is that the council will frustrate its members and alienate the rest of the NHS; it will become just another committee in an organisation that already has too many.

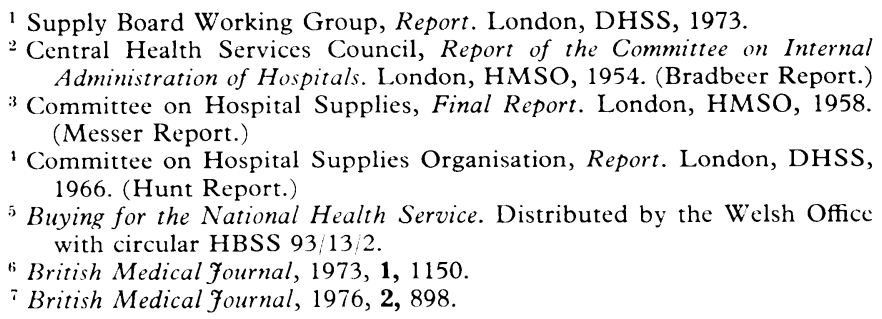

\section{Clues in Perthes's disease}

We now have ample histological evidence that the underlying disorder in Perthes's disease is a healing infarct of the femoral head epiphysis. ${ }^{1-3}$ Further, many data suggest that the epiphysis in many, if not all, instances has been implicated in more than one ischaemic episode. Repetition of the ischaemia explains the slow clinical course of the disease. Similar pathological changes have been produced in the puppy by imposing repeated ischaemic episodes on the femoral head epiphysis." In man, however, the cause of the repeated infarctions appears complex.

The problems of the disorder are peculiar to the hip. They not only stem from the functional importance of that joint but also reflect a "design fault" in the anatomy of the blood supply to the head of the femur. In children between the ages of 4 and 7 years no important vessels cross the epiphysial plate and a blood supply through the ligamentum teres has yet to develop." Over this period the epiphysis is nourished entirely by the lateral epiphysial vessels running along the femoral neck posterosuperiorly under the periosteum. Here they are in a position to be compressed and even occluded by an effusion in the hip joint. ${ }^{6}$ During the early stages of Perthes's disease venography has shown delayed venous outflow from the medulla of the femoral neck and diminished filling of the capsular veins. Perthes's disease occurs at an age when transient synovitis of the hip is common, and indeed in a few instances it has followed a clinically evident effusion. Yet more often the onset of the disease is silent and the precipitating cause obscure.

The disease is most common between the ages of 4 and 7 ; it affects one or two children in a thousand and boys four times as often as girls. One case in 10 is bilateral. It is rare in negroes. If confusion with cases of multiple epiphysial and other bone dysplasias is eliminated very little genetic predisposition is demonstrable. The disorder appears in only $1{ }^{\circ}{ }_{0}$ of first-degree relatives and with no excess at all in second and third degree relations. ${ }^{*}$ Surprisingly and inexplicably there appears to be an excess of abnormalities of the groin and genitourinary system among both patients and their near relatives. ${ }^{9}$ Recent painstaking anthropometric studies have shown that at the time of the onset of their hip disease many affected children are retarded in skeletal maturation and growth. ${ }^{10-13}$ As judged from hand radiographs skeletal age may remain at a standstill for three or more years, although later it catches up completely or nearly so. There is associated delay in growth, the children being smaller in every dimension except head circumference, but particularly distally in the limbs. ${ }^{14}$ In one study ${ }^{8}$ children with Perthes's disease appeared to suffer from an unduly high proportion of unfavourable environmental factors. Before birth malposition was some three times more frequent than normal. They tended to be born late in their family, from parents of higher than usual age, and into low-income households.

The frequency of bilateral disease has long suggested the existence of a predisposition to the disorder in at least some patients. We now have evidence that perhaps in most cases there is a general abnormality of skeletal development at the time when the hip disease starts. Many questions remain. How does delayed skeletal maturation increase the risks of the period when the blood supply to the femoral epiphysis depends exclusively and precariously on the lateral epiphysial vessels? Does the more rapid skeletal maturation seen in girls and negroes confer protection? Do the environmental handicaps act by delaying skeletal development? How important are other, perhaps hormonal, causes of impaired growth? We must hope that these new clues will lead to a fuller understanding that may allow the effective prophylaxis that is so needed for a condition often unsatisfactory to treat.

${ }^{1}$ McKibbin, B, and Ralis, Z, Fournal of Bone and foint Surgery, 1974, 56B, 438.

2 Jensen, O M, and Lauritzen, J, fournal of Bone and Foint Surgery, 1976, $\mathbf{5 8 B}, 332$.

${ }^{3}$ Inoue, A, et al, fournal of Bone and foint Surgery, 1976, 58B, 453.

4 Sanchis, M, Zahir, A, and Freeman, M A R, fournal of Bone and foint Surgery, 1973, 55A, 335.

5 Trueta, J, fournal of Bone and foint Surgery, 1957, 39B, 358.

${ }^{6} \mathrm{Kemp}, \mathrm{H}$, Annals of the Royal College of Surgeons of England, 1973, 52, 18.

' Suramo, I, et al, fournal of Bone and foint Surgery, 1974, 56B, 448.

${ }^{8}$ Wynne-Davies, R, and Gormley, J, Fournal of Bone and foint Surgery, $1978,60 B, 6$.

${ }^{9}$ Catterall, A, Lloyd-Roberts, G C, and Wynn-Davies, R, Lancet, 1971, 1, 995.

10 Goff, C W, Legg-Calve-Perthes' Syndrome and Related Osteochondroses of Youth. Springfield, Illinois, Charles C Thomas, 1954.

11 Girdany, B R, and Osman, M Z, Radiologic Clinics of North America, 1968, 6, 245.

${ }^{12}$ Fisher, R L, Fournal of Bone and foint Surgery, 1972, 54A, 769.

${ }^{13}$ Harrison, M H M, Turner, M H, and Jacobs, P, fournal of Bone and foint Surgery, 1976, 58B, 37.

${ }^{14}$ Burwell, R G, et al, British Orthopaedic Association Spring Meeting, 1978.

\section{What should he eat, doctor?}

Relatives looking after a patient with acute myocardial infarction at home will almost invariably ask the doctor what he should eat. Equally commonly his answer will be to give the patient "light meals only," perhaps restricting fats and cholesterol-advice which is as bland as the diet, although recommended in many standard textbooks. ${ }^{1}$ Even in coronary care units dietary policy tends to be vague if not non-existent. Surprisingly we still seem to be in the dark about the correct regimen to give the patient in the acute phase of the illness. The problem has been highlighted by the results of a recent survey ${ }^{2}$ in the USA, which showed that the diet given to patients with acute infarction varied considerably from hospital to hospital, although $60 \%$ of institutions did have a "routine CCU diet." Most hospitals in Britain give such patients the ordinary ward diet, perhaps with some restriction of calories.

There are two separate aspects to the diet of the patient with 